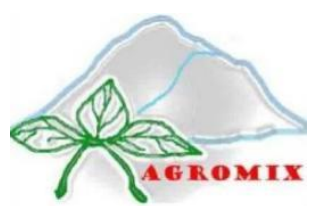

\title{
AGROMIX
}

Jurnal IImiah Fakultas Pertanian, Universitas Yudharta Pasuruan pISSN (Print): 2085-241X; eISSN (Online): 2599-3003

Website: https://jurnal.yudharta.ac.id/v2/index.php/agromix

\section{Analisis daya saing ubi jalar di Kabupaten Karanganyar}

\author{
Competitiveness analysis of sweet potato of Karanganyar District
}

\author{
Ardina Nur Halimah ${ }^{1}$, Endang Siti Rahayu ${ }^{1}$, Ernoiz Antriyandarti ${ }^{1 *}$ \\ ${ }^{1}$ Fakultas Pertanian, Universitas Sebelas Maret Surakarta, Surakarta, Jawa Tengah, Indonesia \\ *Email korespondensi: ernoiz_a@staff.uns.ac.id
}

\section{Article History}

Received : September 23, 2020

Accepted : February 28, 2021

Published : March 30, 2021

\section{Keyword}

Comparative Advantage; Competitive Advantage; PAM; Sweet Potato

\section{ABSTRACT}

Sweet potato is a food crop that is easily found and easy to cultivate, can be used as a substitute good for rice and maize. This study aims to determine the competitive and comparative advantages of sweet potato farming and to analyze government policies and their relation to the competitiveness of sweet potato farming in the Karanganyar district. The data analysis method used is the Policy Analysis Matrix (PAM) method. The determination of the sample areas was carried out deliberately in the Tawangmangu, Ngargoyoso, and Jumantono Districts, Karanganyar Regency. The respondents were 60 farmers. The results showed that the private profit was IDR $22,459,017.68$ and a PCR value of 0.49 , then the social benefit is IDR $71,826,979.74$ and a DRCR value of 0.23 which means that the sweet potato commodity also has a competitive and comparative advantage. The output policy parameter consists of an output transfer of -IDR $49,894,031.87$ and an NPCO ratio of 0.48 , which means output policy has not been effective, indicated by the low domestic sweet potato price. The Input policy parameters consist of an Input transfer value of -IDR $804,269.45$, an NPCI ratio of 0.54 , and a factor transfer value of IDR 278,199.64, which means Input policy has protection from the government, fertilizer subsidies, and nontradeable Inputs subject to land tax. The Input-output policy parameters consist of a net transfer of IDR $49,367,962.06$, an EPC value of 0.48 , and an SRP value of -0.52 , which means the Input-output policy has not been provided economic incentives, as a result, farmers spend higher production costs.

\section{Riwayat Artikel \\ Dikirim : 23 September 2020 \\ Disetujui : 28 Pebruari 2021 \\ Diterbitkan : 30 Maret 2021}

\section{Kata Kunci}

Keunggulan Komparatif; Keunggulan Kompetitif;

PAM; Ubi Jalar

\section{ABSTRAK}

Ubi jalar merupakan salah satu tanaman pangan yang mudah dijumpai serta mudah dibudidayakan. Hal ini menjadi alasan ubi jalar dapat dijadikan makanan pengganti (substitusi) nasi maupun jagung. Penelitian ini bertujuan untuk mengetahui keunggulan kompetitif dan komparatif usahatani ubi jalar serta menganalisis kebijakan pemerintah dan kaitannya terhadap daya saing usahatani ubi jalar di Kabupaten Karanganyar. Metode analisis data yang digunakan yaitu metode Policy Analysis Matrix (PAM). Penentuan daerah sampel dilakukan secara sengaja di Kecamatan Tawangmangu, Ngargoyoso, dan Jumantono, di Kabupaten Karanganyar. Jumlah responden sebanyak 60 petani. Hasil penelitian menunjukkan keuntungan privat sebesar $\mathrm{Rp} 22.459 .017,68$ dan nilai PCR sebesar 0,49 artinya komoditas ubi jalar memiliki keunggulan kompetitif. Keuntungan sosial yaitu Rp 71.826.979,74 dan nilai DRCR sebesar 0,23 artinya komoditas tersebut juga memiliki keunggulan komparatif. Parameter kebijakan output terdiri dari transfer output sebesar -Rp 49.894.031,87 dan rasio NPCO sebesar 0,48. Parameter kebijakan Input terdiri dari nilai transfer Input sebesar -Rp 804.269,45, rasio NPCI sebesar 0,54, dan nilai transfer faktor sebesar Rp 278.199,64. Parameter kebijakan Input-output terdiri dari transfer bersih sebesar Rp 49.367.962,06, nilai EPC sebesar 0,48, dan nilai SRP sebesar -0,52. Artinya kebijakan output ubi jalar belum efektif ditunjukkan dengan harga ubi jalar dalam negeri masih rendah. Kebijakan Input tradeable memiliki proteksi dari pemerintah, adanya subsidi pupuk dan Input nontradeable yang dikenai pajak tanah. Kebijakan Input-output belum memberikan insentif ekonomi menyebabkan petani mengeluarkan biaya produksi lebih besar.

Sitasi: Halimah, A. N., Rahayu, E. S., \& Antriyandarti, E. (2021). Analisis daya saing ubi jalar di kabupaten Karanganyar. Agromix, 12(1), 25-32. https://doi.org/10.35891/agx.v12i1.2284

\section{PENDAHULUAN}

Diversifikasi pangan dapat dilakukan dengan meningkatkan konsumsi umbi-umbian, salah satunya ubi jalar. Tanaman ubi jalar mudah ditemui masyarakat karena petani mudah mengelola dan membudidayakannya serta dapat tumbuh di berbagai jenis tanah. Keragaman sifat dan jenis lahan berbeda mempengaruhi pertumbuhan dan produksi ubi jalar (Solihin dkk., 2017). 
Ubi jalar mengandung sumber karbohidrat non biji pengganti nasi (Serly dkk., 2013; Wang dkk., 2013) yang memiliki manfaat sebagai bahan pangan, pakan ternak, dan bahan industri (Arianti \& Harinta, 2021; Irhami dkk., 2019). Selain itu, ubi jalar dapat dimanfaatkan sebagai obat demam berdarah, daun ubi jalar ungu dapat menaikkan trombosit darah (Ayeleso dkk., 2016; Kharisma dkk., 2021; Prasetyaningsih dkk., 2019).

Ubi jalar memiliki banyak varietas, dari ungu, putih, kuning. Hal ini dikarenakan adanya perbedaan pigmen antosianin (warna merah-ungu). Warna menyebar dengan pola cincin tipis pada korteks, bentuk cincin lebar korteks, bercak berkelompok melingkar, cincin tipis bagian daging umbi, cincin lebar daging umbi, dan menutup semua di bagian daging umbi. Antosianin ubi jalar didominasi sianidin dan peonidin (Hasan dkk., 2019; Montilla dkk., 2011; Oliveira dkk., 2019).

Ubi jalar merupakan komoditas unggulan yang berdaya saing industri karena permintaan ekspornya tinggi (Hapsari dkk., 2019). Produksi dapat ditingkatkan dengan teknik budidaya tepat, baik dari pemilihan bahan tanam, model tanam serta pemilihan varietas sesuai dengan kondisi tanah dan lingkungan (Rohaeni \& Marhani, 2018). Petani biasa memasarkan ubi jalar kepada tengkulak dengan tawar menawar (Pradika dkk., 2013).

Saat ini, volume ekspor ubi jalar lebih tinggi dibandingkan volume impornya. Menurut (Badan Pusat Statistik, 2018b), pada tahun 2018 nilai ekspor ubi jalar sebesar US\$ 9.768.708 dengan volume ekspornya 11.392 ton, sedangkan nilai impor ubi jalar sebesar US\$13.244 dengan volume impor $9.192 \mathrm{~kg}$ (Badan Pusat Statistik, 2018a). Artinya ubi jalar Indonesia diterima di pasar internasional, namun impor tetap dilakukan dalam memenuhi kebutuhan domestik karena keterbatasan produksi seperti adanya gap waktu panen ubi jalar maupun perubahan faktor iklim dan cuaca.

Indonesia masih mengekspor ubi jalar dalam bentuk segar sehingga harga jual rendah dan tidak dapat bersaing dengan produk olahan lainnya yang memiliki nilai jual tinggi (Hoeridah \& Sarianti, 2011). Ekspor ubi jalar biasanya ke Korea Selatan dan Jepang.

Ekspor ubi jalar yang semakin meningkat dapat menjadikan ubi jalar sebagai salah satu komoditas unggulan berdaya saing (Hoeridah \& Sarianti, 2011). Komoditas unggulan di suatu wilayah menjadi acuan pemerintah dalam memprioritaskan peningkatan produksi komoditas tersebut dan sarat akan kebijakan pertanian (Septarisco \& Prihtanti, 2019).

Penelitian ini bertujuan untuk mengetahui keunggulan kompetitif dan komparatif usahatani ubi jalar serta menganalisis kebijakan pemerintah dan kaitannya terhadap daya saing usahatani ubi jalar di Kabupaten Karanganyar.

\section{METODE}

Metode penentuan daerah sampel dilakukan secara sengaja dengan memilih Kecamatan Tawangmangu, Ngargoyoso, dan Jumantono di Kabupaten Karanganyar sebagai tempat penelitian yang memiliki produktivitas dan produksi tertinggi. Penetuan petani sampel menggunakan metode snowball sampling dengan sampel sebanyak 60 petani.

Metode analisis data yang digunakan yaitu Policy Analysis Matrix (PAM). Analisis data menggunakan metode PAM lebih terperinci dengan memiliki teknik akuntansi ganda yang dapat merangkum seluruh biaya domestik dalam kegiatan produksi pertanian maupun pasca panennya serta efisiensi laba (Kanaka \& Chinnadurai, 2013). Metode PAM digunakan dalam menganalisis keunggulan kompetitif dan komparatif serta menganalisis kebijakan pemerintah dan kaitannya terhadap daya saing usahatani ubi jalar.

\section{Analisis keunggulan kompetitif dan komparatif}

1. Identifikasi Input dan output usahatani ubi jalar. Input yang digunakan yaitu lahan (ha), benih (kg), pupuk (kg), pestisida, tenaga kerja (HOK), dan alat pertanian (unit). Output yang dihasilkan yaitu ubi jalar.

2. Alokasi biaya produksi kedalam komponen tradeable dan non-tradeable berdasarkan jenis Input dan penilaian biaya Input tersebut.

3. Alokasi biaya tataniaga sampai ke lokasi penelitian terdiri dari biaya bongkar muat sampai pengangkutan, termasuk dalam komponen non-tradeable.

4. Menghitung harga bayangan output menggunakan harga batas ekspor yaitu FOB dikurangi dengan biaya tataniaga berdasarkan rata-rata harga ekspor ubi jalar tahun 2020.

5. Menghitung harga bayangan Input non-tradeable menggunakan harga aktual pada lokasi penelitian. Input nontradeable yang dimaksud yaitu Input benih, sewa lahan, pupuk kandang, dan penyusutan alat.

6. Menghitung harga bayangan tenaga kerja dengan rumus :

HBTK $=(80 \%-\%$ pengangguran $) \times$ HATK

Keterangan :

HATK = Harga Aktual Tenaga Kerja

HBTK = Harga Bayangan Tenaga Kerja (Pearson dkk., 2004) 
7. Harga bayangan pupuk tradeable seperti pupuk urea, phonska, ZA, KCL, SP-36 menggunakan harga batas impor CIF ditambahkan dengan biaya tataniaga sampai ke petani. Hal ini dikarenakan bahan baku dalam pembuatan pupuk anorganik sebagian masih impor.

8. Harga bayangan pestisida baik padat maupun cair menggunakan harga batas impor yaitu CIF ditambahkan dengan biaya tata niaganya sampai ke petani.

9. Harga bayangan nilai tukar atau shadow exchange rate (SER) menggunakan rumus Gittinger (1986) yaitu :

SER $=$ OER

$$
\text { SER }=\frac{X t+M t}{(X t-T X t)+(M t-T M t)}
$$

Keterangan :

$\mathrm{SER}=$ Nilai tukar bayangan (Rp/US\$)

OER = Nilai tukar resmi (Rp/US\$)

SCFt = Faktor konversi standar tahun ke-t

$\mathrm{Xt} \quad=$ Nilai ekspor Indonesia tahun ke-t (Rp)

$\mathrm{Mt}=$ Nilai impor Indonesia tahun ke-t (Rp)

$\mathrm{TXt} \quad=$ Penerimaan pemerintah dari pajak ekspor tahun ke-t (Rp)

$\mathrm{TMt}=$ Penerimaan pemerintah dari pajak impor tahun ke-t (Rp)

Nilai tukar yang digunakan yaitu rata-rata nilai tukar rupiah tahun 2019.

Setelah menghitung penerimaan dan biaya produksi dari usahatani ubi jalar di Kabupaten Karanganyar kemudian dimasukkan pada matriks PAM untuk menganalisis keunggulan kompetitif dan komparatif ubi jalar seperti pada tabel berikut :

Tabel 1. Tabulasi matriks PAM

\begin{tabular}{lcccc}
\hline \multirow{2}{*}{ Uraian } & & \multicolumn{2}{c}{ Biaya } & \\
\cline { 3 - 4 } & Penerimaan & $\begin{array}{c}\text { Input } \\
\text { Tradeable }\end{array}$ & $\begin{array}{c}\text { Input non- } \\
\text { tradeable }\end{array}$ & Keuntungan \\
\hline Harga Privat & $\mathrm{A}$ & $\mathrm{B}$ & $\mathrm{C}$ & $\mathrm{D}=\mathrm{A}-\mathrm{B}-\mathrm{C}$ \\
Harga Sosial & $\mathrm{E}$ & $\mathrm{F}$ & $\mathrm{G}$ & $\mathrm{H}=\mathrm{E}-\mathrm{F}-\mathrm{G}$ \\
Efek Divergensi & $\mathrm{I}=\mathrm{A}-\mathrm{E}$ & $\mathrm{J}=\mathrm{B}-\mathrm{F}$ & $\mathrm{K}=\mathrm{C}-\mathrm{G}$ & $\mathrm{L}=\mathrm{D}-\mathrm{H}$ \\
\hline
\end{tabular}

Sumber: (Pearson dkk., 2004)

Keterangan:

$A=$ Penerimaan privat

$\mathrm{B}=$ Total biaya Input tradeable privat

C = Total biaya Input non-tradeable privat

$\mathrm{D}=$ Keuntungan privat

$\mathrm{E}=$ Penerimaan sosial

$\mathrm{F}=$ Total biaya Input tradeable sosial

G = Total biaya Input non-tradeable sosial

$\mathrm{H}=$ Keuntungan sosial

I = Transfer output

$\mathrm{J}=$ Transfer Input tradeable

$\mathrm{K}=$ Transfer faktor domestik

$\mathrm{L}=$ Transfer bersih

Indikator dalam analisis keunggulan kompetitif yaitu Privat Cost Ratio (PCR) dan total keuntungan privat. PCR didapatkan dari perbandingan antara total biaya privat Input non-tradeable dengan selisih penerimaan privat dan total biaya privat Input tradeable. Jika nilai PCR kurang dari satu dan keuntungan privat positif maka usahatani tersebut dikatakan memiliki keunggulan kompetitif serta secara finansial menguntungkan.

Sedangkan, analisis keunggulan komparatif menggunakan Domestic Resource Cost Ratio (DRCR) dan total keuntungan sosial. DRCR didapatkan dari perbandingan antara total biaya sosial Input non-tradeable dengan selisih penerimaan sosial dan total biaya sosial Input tradeable. Jika nilai DRCR kurang dari satu dan keuntungan sosial positif maka usahatani tersebut memiliki keunggulan komparatif serta memiliki keuntungan secara sosial.

\section{Analisis kebijakan pemerintah serta kaitannya terhadap usahatani ubi jalar di Kabupaten Karanganyar}

1. Kebijakan output

a) Transfer output (simbol I dalam matriks PAM) menunjukkan adanya divergensi pada harga output menyebabkan penerimaan privat berbeda dengan sosial.

$$
\mathrm{I}=\mathrm{A}-\mathrm{E}
$$

Keterangan :

I $>0$ = timbulnya implisit subsidi atau transfer sumberdaya yang menambah keuntungan sistem

$\mathrm{I} \leq 0$ = terjadi implisit pajak atau transfer sumberdaya yang mengurangi keuntungan sistem

b) Koefisien proteksi output nominal (NPCO) digunakan dalam mengukur transfer output yang menunjukkan perbedaan besar harga privat dengan harga sosial.

$\mathrm{NPCO}=\mathrm{A} / \mathrm{E}$ 


\section{Keterangan:}

NPCO $>1$ = kebijakan bersifat proteksi terhadap output dan semakin besar nilai NPCO semakin tinggi tingkat proteksi terhadap output

$\mathrm{NPCO} \leq 1$ = kebijakan bersifat disinsentif

2. Kebijakan Input

a) Transfer Input (simbol J dalam matriks PAM) merupakan selisih antara biaya Input tradeable pada harga privat dengan biaya Input tradeable harga sosial. Jika nilai transfer Input lebih besar dari nol maka adanya transfer petani ke produsen Input tradeable. Namun, jika nilai transfer Input kurang dari sama dengan ( $\leq$ ) satu maka tidak adanya transfer dari petani ke produsen Input tradeable.

b) Koefisien proteksi Input nominal (NPCI) menunjukkan tingkat proteksi pemerintah terhadap Input tradeable.

$$
\mathrm{NPCl}=\mathrm{B} / \mathrm{F}
$$

Keterangan:

$\mathrm{NPCl}<1$ = kebijakan bersifat protektif terhadap Input, adanya subsidi terhadap Input tradeable

$\mathrm{NPCl} \geq 1$ = tidak ada kebijakan bersifat protektif terhadap Input tradeable

c) Transfer faktor (simbol K dalam matriks PAM) didapatkan dari selisih antara biaya Input non-tradeable pada harga privat maupun sosial. Jika didapatkan nilai transfer faktor lebih dari nol maka terdapat subsidi negatif (pajak) pada Input non-tradeable. Sebaliknya, jika nilai transfer faktor nol atau lebih besar dari nol maka terdapat subsidi positif pada Input non-tradeable.

3. Kebijakan Input-output

a) Transfer bersih (simbol L pada matriks PAM) didapatkan dari selisih antara keuntungan privat dengan keuntungan sosial. Jika nilai transfer bersih lebih dari nol maka ada tambahan surplus produsen disebabkan kebijakan pemerintah yang diterapkan pada Input maupun output. Namun, jika nilai transfer bersih nol atau kurang dari nol maka tidak ada tambahan surplus produsen disebabkan kebijakan pemerintah yang diterapkan pada Input maupun output.

b) Koefisien protektif efektif (EPC) digunakan dalam menunjukkan sejauh mana kebijakan pemerintah melindungi atau menghambat produksi dalam negeri.

$$
E P C=(A-B) /(E-F)
$$

Keterangan:

EPC $>1$ = kebijakan bersifat protektif, semakin besar nilai EPC maka semakin tinggi proteksi pemerintah terhadap komoditas domestik

EPC $\leq 1$ = kebijakan tidak bersifat protektif, tidak ada proteksi pemerintah terhadap komoditas domestik

c) Rasio subsidi bagi produsen (SRP) digunakan dalam mengukur dampak transfer dari perbandingan transfer bersih dengan penerimaan sosial. Jika nilai SRP kurang dari nol maka kebijakan pemerintah yang berlaku menyebabkan produsen mengeluarkan biaya produksi lebih besar dari biaya imbangan untuk berproduksi. Sebaliknya, jika nilai SRP nol atau lebih besar dari nol maka kebijakan pemerintah yang berlaku tidak menyebabkan produsen mengeluarkan biaya produksi lebih besar dari biaya imbangan untuk berproduksi.

\section{HASIL DAN PEMBAHASAN}

\section{Karakteristik petani sebagai responden}

Dari 60 petani ubi jalar di Kabupaten Karanganyar, 93\% petani termasuk usia produktif dengan usia antara 15-64 tahun. Artinya, petani di sana memiliki fisik yang potensial dalam mendukung kegiatan usahatani dinamis, kreatif, dan cepat dalam menerima inovasi teknologi baru (Samun dkk., 2011). Pendidikan yang telah ditempuh petani terakhir mayoritas SD sebanyak 40\% petani. Dilihat dari segi lama berusahatani, sebanyak 55\% petani memiliki pengalaman 515 tahun.

\section{Kegiatan usahatani ubi jalar}

\section{Penguasaan lahan}

Lahan sebesar 17,185 ha untuk ditanami ubi jalar dengan luas per usahatani sebesar 0,2864 ha atau $2.864 \mathrm{~m}^{2}$. Status milik sendiri sebesar 15,485 ha, sewa 0,7 ha, dan sakap sebesar 1 ha. Hal ini dikarenakan biaya sewa di tempat penelitian cukup tinggi serta biaya saprodi dan kebutuhan usahatani cukup banyak sehingga petani lebih memilih menguasai lahan sakap sebagai budidaya.

2. Analisis usahatani ubi jalar

Produksi ubi jalar per musim tanam sebanyak 4.568,33 $\mathrm{kg}$ per usahatani dengan harga jual Rp 2.881,67. Penerimaan rata-rata per usahatani sebesar Rp 12.983.333,33. Sedangkan, rata - rata pendapatan petani ubi jalar sebesar Rp 6.432.784,26 per usahatani atau Rp 22.459.479,76 per hektar. 
Biaya paling banyak dikeluarkan yaitu biaya untuk sewa lahan dan sewa kultivator digolongkan dalam biaya tetap sebesar Rp 3.589.000,00 per usahatani. Biaya paling sedikit dikeluarkan yaitu biaya lain-lain terdiri dari iuran air irigasi dan pajak tanah sebesar Rp 17.185,00 per usahatani. Alat pertanian yang digunakan yaitu cangkul, sabit, sprayer dengan biaya penyusutan sebesar Rp 24.416,92 per usahatani.

Jumlah tenaga kerja dalam keluarga (TKDK) sebesar 18,83 HKO per usahatani dan jumlah tenaga kerja luar keluarga (TKLK) sebesar 7,07 HKO per usahatani. Jumlah biaya tenaga kerja yang dikeluarkan petani sebesar Rp 1.125.205,48 per usahatani.

Sarana produksi yang digunakan petani ubi jalar di Kabupaten Karanganyar yaitu benih, pupuk kandang, pupuk phonska, pupuk urea, pupuk KCL, pupuk ZA, pupuk SP-36, dolomit, herbisida (Phefoc HCS) dan insektisida (Curacron 500 EC dan Permetrin Extratin 200 EC). Jumlah benih ubi jalar sebanyak 10.257,92 batang per usahatani. Jumlah dolomit yang digunakan sebesar $65 \mathrm{~kg}$ per usahatani.

Pupuk yang digunakan setiap petani rata-rata yaitu pupuk kandang sebanyak 139,17 kg; pupuk urea sebanyak 23,75 kg; pupuk phonska sebesar 115,08 kg; pupuk ZA sebesar 46,67 kg; pupuk SP-36 sebesar 6,25 kg; dan pupuk KCL sebesar 3,00 kg. Penggunaan pupuk yang bermacam - macam memiliki dosis yang berbeda - beda tergantung pada kebutuhan lahannya tersebut.

Petani ubi jalar yang menggunakan Phefoc HCS hanya beberapa petani saja sebesar 0,27 botol per usahatani. Insektisida yang digunakan Curacron 500EC dan Permetrin Extratin 200EC. Insektisida Permetrin Extratin baik disemprotkan pada umur 50, 78, 106 hari (Indiati \& Saleh, 2010). Penggunaan Curacron 500EC sebanyak 0,12 botol dan Permetrin Extratin 200EC sebanyak 0,41 botol per usahatani. Total biaya saprodi ubi jalar sebesar Rp 1.794.741,67 per usahatani.

\section{Analisis daya saing usahatani ubi jalar}

\section{Harga bayangan nilai tukar}

Nilai tukar resmi yang digunakan berdasarkan data dari Bank Indonesia rata-rata pada tahun 2019 sebesar Rp $14.139,00 /$ SD. Nilai faktor konversi standar (SFT) diperoleh dari rasio nilai impor dan ekspor ditambah dengan biaya pajaknya. Setelah dikonversi (SFT), nilai tukar bayangan (SER) diperoleh dengan menghitung rasio nilai tukar resmi dengan nilai faktor konversi standar, didapatkan harga bayangan nilai tukar sebesar Rp 14.034,90/USD.

\section{Struktur Input output fisik}

\section{i). Input tradeable}

Seluh Input tradeable (dapat diperdagangkan) usahatani ubi jalar menggunakan harga batas CIF (Cost Insurance and Freight) sebagai harga sosial. Harga sosial Input pupuk ZA yaitu Rp 1.889,36/kg didapatkan dari perkalian antara harga CIF pupuk ZA dengan SER lalu ditambah dengan biaya tata niaganya. Sama halnya dengan harga sosial untuk Input pupuk phonska, urea, SP-36, KCL, insektisida dan herbisida didapatkan dari hasil perkalian harga CIF masingmasing Input untuk usahatani ubi jalar dikalikan dengan nilai SER kemudian ditambah biaya tata niaga. Jumlah Input tradeable pada harga privat yang digunakan sebagai masukan dalam budidaya ubi jalar di Kabupaten Karanganyar sebesar Rp 926.290,99 per hektar sedangkan Input tradeable pada harga sosial sebesar Rp 1.730.560,44 per hektar.

\section{ii). Input non-tradeable}

Input non-tradeable merupakan Input yang diproduksi di pasar domestik. Harga privat Input non-tradeable yaitu benih, pupuk kandang, dan dolomit. Harga privat benih Rp 100,00/batang. Benih ubi jalar yang ditanam di Kabupaten Karanganyar menggunakan stek batang yang sudah dipanen dipilih umbi yang baik dan sehat untuk di stek dan ditanam kembali. Harga privat pupuk kandang yaitu Rp 1.000,00/kg. Harga privat dolomit yaitu Rp 2.500,00/kg.

Selain itu, terdapat penyusutan alat, tenaga kerja baik dari dalam maupun luar keluarga, sewa lahan, iuran air, pajak tanah, dan sewa traktor yang masuk ke dalam Input non-tradeable. Harga privat yang digunakan dalam penyusutan alat yaitu harga rata - rata yang diperoleh petani saat membeli peralatan petani, sebesar Rp 85.249,61 per hektar. Harga privat tenaga kerja yaitu harga upah rata - rata yang berlaku di daerah penelitian. Harga upah rata - rata tenaga kerja dalam keluarga yaitu Rp 80.830,00/HKO. Harga upah rata - rata tenaga kerja luar keluarga yaitu Rp 91.9333,33/HKO. Harga sosial pada keseluruhan Input non-tradeable sama dengan harga privat yang ada di tempat penelitian, kecuali pada harga sosial tenaga kerja baik dalam maupun luar keluarga. Harga sosial tenaga kerja dalam keluarga sebesar Rp 1.525.393,05 per hektar dan harga sosial tenaga kerja luar keluarga sebesar Rp 1.492.920,50 per hektar. Jadi total seluruh Input non-tradeable pada harga privat sebesar Rp 21.944.868,43 per hektar sedangkan jumlah keseluruhan Input non-tradeable pada harga sosial Rp 21.666.668,80 per hektar.

\section{iii). Output}

Harga privat output ubi jalar berdasarkan pada harga yang ada di tempat penelitian sebesar Rp 2.881,67/kg. Harga output ubi jalar menggunakan harga batas FOB (Free On Board) dikarenakan output ubi jalar merupakan output tradeable. Harga sosial output ubi jalar di tingkat petani sebesar Rp 5.970,19/kg. 
3. Analisis daya saing menggunakan metode policy analysis matrix (PAM)

Tabel 2. Matriks analisis kebijakan (policy analysis matrix) per hektar

\begin{tabular}{lcccc}
\hline \multirow{2}{*}{ Uraian } & \multirow{2}{*}{ Penerimaan } & \multicolumn{2}{c}{ Input } & \multirow{2}{*}{ Keuntungan } \\
\cline { 3 - 4 } Harga Privat & $45.330 .177,10$ & $926.290,99$ & $21.944 .868,43$ & $22.459 .017,68$ \\
Harga Sosial & $95.224 .208,97$ & $1.730 .560,44$ & $21.666 .668,80$ & (C) \\
& $(\mathrm{E})$ & $(\mathrm{F})$ & $(\mathrm{G})$ & $71.826 .979,74$ \\
Efek & $(49.894 .031,87)$ & $(804.269,45)$ & $278.199,64$ & $(\mathrm{H})$ \\
Divergensi & $(\mathrm{I})$ & $(\mathrm{J})$ & $(\mathrm{K})$ & $(49.367 .962,06)$ \\
\hline
\end{tabular}

Sumber: Data primer, 2020

a. Analisis keunggulan kompetitif dan komparatif ubi jalar di Kabupaten Karanganyar (tujuan pertama)

Tabel 3. Indikator keunggulan kompetitif dan komparatif usahatani ubi jalar di Kabupaten Karanganyar

\begin{tabular}{llcc}
\hline No & \multicolumn{1}{c}{ Uraian } & Parameter & Nilai \\
\hline 1 & Keunggulan & Keuntungan Privat & $22.459 .017,68$ \\
& Kompetitif & Private Cost Ratio (PCR) & 0,49 \\
2 & Keunggulan & Keuntungan Sosial & $71.826 .979,74$ \\
& Komparatif & Domestic Resources Cost Ratio (DRCR) & 0,23 \\
\hline
\end{tabular}

Sumber: Data primer, 2020

Keunggulan kompetitif ubi jalar terdiri dari keuntungan privat dan rasio PCR. Nilai keuntungan privat positif sebesar Rp 22.459.017,68 per hektar dan rasio PCR 0,49. Artinya usahatani ubi jalar di Kabupaten Karanganyar memiliki keunggulan kompetitif, menguntungkan secara finansial serta dapat diprioritaskan untuk dikembangkan.

Keunggulan komparatif ubi jalar dapat diketahui dari nilai keuntungan sosial dan rasio DRCR. Keuntungan sosial positif sebesar Rp 71.826.979,74 per hektar dan rasio DRCR yaitu 0,23. Artinya usahatani ubi jalar di Kabupaten Karanganyar memiliki keunggulan komparatif, menguntungkan secara ekonomi dan dapat diprioritaskan untuk dikembangkan. Selain itu, dalam penggunaan sumberdaya domestik, pemenuhan permintaan komoditas ubi jalar dalam negeri lebih menguntungkan jika diproduksi sendiri.

b. Analisis kebijakan pemerintah (tujuan kedua)

i). Kebijakan output

Indikator yang digunakan yaitu transfer output dan rasio NPCO. Nilai transfer Input sebesar -Rp 49.894.031,87 per hektar. Artinya penerimaan pada harga privat lebih rendah dibandingkan penerimaan harga sosial, selain itu diartikan adanya implisit pajak sehingga mengurangi keuntungan usahatani ubi jalar di Kabupaten Karanganyar karena harga output yang diterima petani lebih rendah dari harga sebenarnya. Rasio NPCO yaitu 0,48 artinya produsen domestik menerima harga jual lebih rendah $48 \%$ dari harga pasar dunia, pemerintah menunjukkan disproteksi terhadap harga output ubi jalar.

ii). Kebijakan Input

Indikator yang digunakan yaitu transfer Input, NPCI, dan transfer faktor. Nilai transfer Input sebesar -Rp 804.269,45 per hektar. Artinya tidak adanya transfer dari petani ke produsen Input tradeable. Biaya Input tradeable yang dikeluarkan petani lebih rendah daripada biaya Input tradeable yang seharusnya dikeluarkan.

Rasio NPCl yaitu 0,54 artinya harga Input lebih murah 54\% dari harga seharusnya. Hal ini menunjukkan kebijakan pemerintah bersifat protektif terhadap Input tradeable berupa subsidi pada pupuk ZA, phonska, SP-36, dan urea. Petani tidak membayar penuh dalam pembelian pupuk tersebut. Transfer faktor nilainya positif sebesar Rp 278.199,64 per hektar, artinya terjadi subsidi negatif dari pemerintah terhadap Input non-tradeable berupa pajak lahan milik sendiri.

\section{iii). Kebijakan Input - output}

Indikator yang digunakan dalam menganalisis kebijakan Input-output yaitu transfer bersih, EPC, dan SRP. Besar nilai transfer bersih negatif yaitu -Rp 49.367.962,06 per hektar, artinya kebijakan pemerintah berupa subsidi pada Input dan output masih belum memberikan insentif ekonomi dalam meningkatkan produksi ubi jalar.

Nilai EPC yaitu 0,48 artinya tingkat proteksi pemerintah terhadap produksi ubi jalar dalam negeri masih rendah. Hal ini ditunjukkan harga jual ubi jalar dalam negeri masih rendah dibandingkan pada pasar internasional.

Besar nilai EPC yaitu -0,52 artinya kebijakan pemerintah terhadap ubi jalar menyebabkan petani mengeluarkan biaya produksi lebih besar. Hal ini dikarenakan petani memiliki keterbatasan ilmu pengetahuan dan kemampuan dalam budidaya serta adaptasi teknologi yang digunakan masih kurang sehingga dalam memanfaatkan sumberdaya belum efisien. Petani hanya mampu mengandalkan bantuan dari pemerintah. 


\section{KESIMPULAN}

Komoditas ubi jalar di Kabupaten Karanganyar memiliki nilai PCR sebesar 0,49 dan nilai DRCR sebesar 0,23. Hal ini berarti komoditas ubi jalar memiliki daya saing berdasarkan keunggulan kompetitif dan komparatif. Dilihat dari kebijakan output ubi jalar sendiri dinilai masih belum efektif ditunjukkan harga ubi jalar dalam negeri masih rendah. Dari segi kebijakan Input tradeable memiliki proteksi dari pemerintah dengan adanya subsidi pupuk dan Input nontradeable yang dikenai pajak tanah. Kebijakan Input-output belum memberikan insentif ekonomi menyebabkan petani mengeluarkan biaya produksi lebih besar. Disarankan 1) Bagi pemerintah diharapkan juga membantu pelatihan terkait pengelolaan pasca panen dan pemasaran ubi jalar seperti meningkatkan ekspor ubi jalar dalam bentuk olahan sehingga dapat meningkatkan pendapatan petani ubi jalar Kabupaten Karanganyar. 2) Bagi pemerintah diharapkan tetap memberikan subsidi dalam bentuk pupuk agar petani dapat meningkatkan produksi ubi jalar yang memiliki daya saing kompetitif yang baik. 3) Bagi petani ubi jalar dalam meningkatkan daya saing didorong untuk mampu meningkatkan produktivitas ubi jalar dan meningkatkan kualitas berupa efisiensi teknologi dengan menggunakan bibit ubi jalar yang berkualitas unggul.

\section{DAFTAR PUSTAKA}

Arianti, Y. S., \& Harinta, Y. W. (2021). Sweet potatoes: development and potential as alternative food ingredients in Karanganyar Regency, Indonesia. E3S Web of Conferences, 226, 00050. https://doi.org/10.1051/e3sconf/202122600050

Ayeleso, T. B., Ramachela, K., \& Mukwevho, E. (2016). A review of therapeutic potentials of sweet potato: Pharmacological activities and influence of the cultivar. Tropical Journal of Pharmaceutical Research, 15(12), 27512761. https://doi.org/10.4314/tjpr.v15i12.31

Badan Pusat Statistik. (2018a). Buletin statistik perdagangan impor. BPS RI. https://www.bps.go.id/publication/2019/03/08/ea346e54318cc90f1df48c65/buletin-statistik-perdagangan-luarnegeri-impor-desember-2018.html

Badan Pusat Statistik. (2018b). Buletin statistik perdagangan luar negeri ekspor. BPS RI. https://www.bps.go.id/publication/2019/03/01/96bf32ca9121c654f43d2315/buletin-statistik-perdagangan-luarnegeri-ekspor-menurut-hs--desember-2018.html

Hapsari, H., Rasmikayati, E., Kurniawan, A., \& Saefudin, B. R. (2019). Karakteristik petani dan profil usahatani ubi jalar di kecamatan arjasari, kabupaten bandung. Sosiohumaniora - Jurnal IImu-ilmu Sosial dan Humaniora, 21(3), 247255.

Hasan, A. P. D., Tianigut, G., \& Pradana, O. C. P. (2019). Seleksi tanam tunggal 14 klon ubi jalar (Ipomoea batatas L.) berantosianin dan berumbi besar dari induk ayamurasaki. Jurnal Planta Simbiosa, 1(1).

Hoeridah, A. P. D., \& Sarianti, T. (2011). Analisis daya saing ubi jalar cilembu di kabupaten Sumedang Jawa Barat. Jurnal Planta Simbiosa, 1(1), 67-77.

Indiati, S. W., \& Saleh, N. (2010). Hama boleng pada tanaman ubi jalar dan pengendaliannya. Buletin Palawija, 19, 2737.

Irhami, Anwar, C., \& Kemalawaty, M. (2019). Karakteristik sifat fisikokimia pati ubi jalar dengan mengkaji jenis varietas dan suhu pengeringan. Jurnal Teknologi Pertanian, 20(1), 33-44.

Kanaka, \& Chinnadurai. (2013). The policy analysis matrix of rice cultivation in India. European Journal of Physical and Agricultural Sciences, 1(1), 8-19.

Kharisma, V. D., Probojati, R. T., Murtadlo, A. A. A., Ansori, A. N. M., Antonius, Y., \& Tamam, M. B. (2021). Revealing potency of bioactive compounds as inhibitor of dengue virus (DENV) NS2B/NS3 protease from sweet potato (Ipomoea batatas L.) leaves. Indian Journal of Forensic Medicine \& Toxicology, 15(1), 1627-1632.

Montilla, E. C., Hillebrand, S., \& Winterhalter, P. (2011). Anthocyanins in purple sweet potato (Ipomoea batatas L.) varieties. Fruit, Vegetable and Cereal Science and Biotechnology, 5(2), 19-23.

Oliveira, H., Basílio, N., Pina, F., Fernandes, I., de Freitas, V., \& Mateus, N. (2019). Purple-fleshed sweet potato acylated anthocyanins: Equilibrium network and photophysical properties. Food Chemistry, 288, 386-394. https://doi.org/10.1016/j.foodchem.2019.02.132

Pearson, S., Gotsch, C., \& Bahri, S. (2004). Applications of the policy analysis matrix in indonesian agriculture. Yayasan Obor Indonesia.

Pradika, A., Hasyim, A. I., \& Soelaiman, A. (2013). Analisis efisiensi pemasaran ubi jalar di kabupaten Lampung Tengah. JIIA, 1(1), 25-35.

Prasetyaningsih, Y., Sari, N., Prasetya, H. R., \& Naer, V. G. (2019). Potensi etnomedicine daun ubi jalar ungu (Ipomoea batatas L. Poir) dan daun ubi jalar putih (Ipomoea batatas L.) sebagai obat demam berdarah di Sleman DIY. Journal of Health, 6(1), 6-11.

Rohaeni, N., \& Marhani. (2018). Uji pertumbuhan dan produksi ubi jalar (Ipomoea batatas L.) terhadap model tanam dan interval penyiangan gulma. Jurnal Pertanian Terpadu, 6(2), 64-75. 
Samun, S., Rukmana, D., \& Syam, S. (2011). Partisipasi petani dalam penerapan teknologi pertanian organik pada tanaman stroberi di Kabupaten Bantaeng. Jurnal Pertanian, 2(1), 1-12.

Septarisco, Y. K. N. J., \& Prihtanti, T. M. (2019). Daya saing usahatani padi di kecamatan susukan kabupaten Semarang menggunakan metode PAM (Policy Analysis Matrix). Jurnal Ilmiah Agrineca, 19(1), 1-16.

Serly, Sengin, E. L., \& Riadi, Muh. (2013). Respon pertumbuhan dan produksi ubi jalar (Ipomoea batatas L.) yang diaplikasikan paclobutrazol dan growmore 6-30-30 [Thesis]. Universitas Hasanuddin Makassar.

Solihin, M. A., Sitorus, S. R. P., Sutandi, A., \& Widiatmaka. (2017). Karakteristik lahan dan kualitas kemanisan ubi jalar cilembu. Jurnal Pengelolaan Sumberdaya Alam dan Lingkungan, 7(3), 251-259.

Wang, M., Shi, Y., Xia, X., Li, D., \& Chen, Q. (2013). Life-cycle energy efficiency and environmental impacts of bioethanol production from sweet potato. Bioresource Technology, 133, $285-292$. https://doi.org/10.1016/j.biortech.2013.01.067 